\title{
Engineering
}

\section{Characterization of Extracellular Polymeric Substances (Eps) Produced by Cloacibacterium normanense Isolated from Wastewater Sludge for Sludge Settling and Dewatering}

Klai Nouha ${ }^{1}$, Hoang NV ${ }^{2}$, Yan Song ${ }^{1}$, Tyagi RD ${ }^{1 *}$ and Surampalli RY ${ }^{3}$

${ }^{1}$ University of Quebec, Institut National de la Recherche Scientifique, Centre Eau, Terre \& Environnement, 490 de la Couronne, Québec, G1K 9A9, Canada 2IET-VAST, 18 Hoang Quoc Viet, Hanoi, Vietnam

${ }^{3}$ Department of Civil Engineering, University of Nebraska-Lincoln, N104 SEC PO Box 886105 Lincoln, NE 68588-6105, USA

\begin{abstract}
In this study, extracellular polymeric substances (EPSs) producing strain was isolated from municipal wastewater sludge (MWWS). Growth profile and the EPS production by Cloacibacterium normanense using wastewater sludge as raw material in shake flask fermentation for $96 \mathrm{~h}$ were investigated. The highest concentration of S-EPS (13.0 \pm $0.8 \mathrm{~g} / \mathrm{L})$ and C-EPS $(0.3 \pm 0.1 \mathrm{~g} / \mathrm{L})$ were attained at $48 \mathrm{~h}$ of fermentation. S-EPS revealed higher flocculation activity $(94.2 \%)$ and dewaterability (59.9\%) than other types of EPS in kaolin suspension. The dewaterability of MWWS with $2 \mathrm{~g}$ suspended solids (SS)/L was improved by $37.6 \%$ using $0.02 \pm 0.01 \mathrm{~g} / \mathrm{L}$ of S-EPS and $600 \mathrm{mg} / \mathrm{L}$ of $\mathrm{Al}_{2}\left(\mathrm{SO}_{4}\right)_{3}$. The study showed a promising approach of new isolated strain to produce high concentration EPS in sludge with high flocculation activity as well as good settling.
\end{abstract}

Keywords: Bioflocculants; Bacterial polymers; Extracellular polymeric substances; Pollution control; Sludge; Wastewater

Abbreviations: APHA: American Public Health Association; B-EPS: Broth EPS; BS: Bacterial Strain; BSA: Bovine Serum Albumin; TP/ TC ratio: Protein to Carbohydrate ratio; C-EPS: Capsular EPS; CFU: Colony Forming Units; CST: Capillary Suction Time; EPS: Extracellular Polymeric Substances; FA: Flocculation Activity; LBEPS: Loosely Bound EPS; mg EPS/g of Kaolin: mg of EPS Added Per Gram of Kaolin Suspension in Water; MWWS: Municipal Wastewater sludge; PCA, Plate Count Agar; PPS: : Pulp and Paper Sludge; S-EPS: Slime EPS; SS: Suspended Solids; SVI: Sludge Volume Index; TBEPS: Tightly Bound EPS; TSB: Tryptic Soy Broth; $\zeta$ : Zeta Potential

\section{Introduction}

Sludge settling and dewatering are the most important steps of wastewater treatment and sludge management. Better dewaterability leads to a sludge economical disposal, reuse as a soil conditioner in agriculture, bricks for construction, and raw material for growing industrial microorganisms [1]. In recent years, researchers have been venturing into bioflocculation of sludge using microorganisms [2] Bioflocculation is defined as an aggregation of bacterial flocs and it is utmost important for efficient separation of microorganisms from the treated effluent. A typical floc is formed by different types of bacteria together with other microorganisms (protozoa, fungi, filamentous microorganisms etc) and viruses along with some abiotic suspended materials. Flocs are held together in a polymeric network of extracellular polymeric substances (EPSs). The microbial EPS plays an important role in bioflocculation by interacting with the sludge solids [3]. The bacterial growth is often accompanied by the production of EPS, which has ecological and physiological functions [4]. EPSs are organic macromolecules that are formed by polymerization of similar or identical building blocks that may be arranged as repeated units within the polymer. The major organic fractions of EPS are carbohydrates and proteins [5]. EPSs also act as excellent emulsifying agents and this property is attributed to the diversity in bacteria [6]. The bacterial EPSs are usually acidic heteropolysaccharides possessing different functional groups (e.g., hydroxyl, carboxyl and phosphoric acid), which exhibit high affinity towards certain metal ions. Many physical and chemical properties of microbial EPSs have led to a wide range of field applications, e.g., adhesion, chelation of heavy metals, coagulation and flocculation, detoxification of toxic compounds, nutrient sequestration, protection against osmotic shock, stabilizers, thickeners, gelling, film-forming and water-retention capability (in detergents, textiles, adhesives, paper, paint, food and beverage industries), oil recovery, mining industry and petroleum industries [2]. A wide range of bacteria from various environmental habitats are known to produce complex and diverse EPS occurring as capsular polysaccharides (C-EPS, strongly associated with the cell surface) or as slime polysaccharides (S-EPS, loosely associated with the cell). Recently, there has been growing interest in the isolation and characterization of microbial EPS owing to their practical importance. Different microorganisms produce various types of EPS with diverse characteristics and concentration. For economic reasons it is essential to find a high EPS yielding microbial strain with high flocculation activity per unit weight of EPS. Therefore, the present study aimed at: i) isolation and identification of high concentration EPS producing bacteria, ii) chemical and physical characterization of the EPS produced by the strain and iii) to evaluate the potential of produced EPS with respect to flocculation activity and dewaterability.

\section{Materials and Methods}

\section{Bacterial strain isolation and identification}

Wastewater sludge samples were collected from Communauté Urbaine du Québec (CUQ, Québec, Canada). EPS producing strain Cloacibacterium Normanense (NK6, accession number KF675204) was isolated from sludge samples using standard plate Count Agar (PCA). The strain was identified based on $16 \mathrm{~S}$ rDNA sequencing.

*Corresponding author: Tyagi RD, University of Quebec, Institut National de la Recherche Scientifique, Centre Eau, Terre and Environnement, 490 de la Couronne, Québec, G1K 9A9, Canada, Tel: +1 418654 2617; E-mail: kalaii.nouha@gmail.com

Received October 02, 2015; Accepted October 13, 2015; Published October 23 2015

Citation: Nouha K, Hoang NV, Song Y, Tagi RD, Surampalli RY (2015) Characterization of Extracellular Polymeric Substances (Eps) Produced by Cloacibacterium normanense Isolated from Wastewater Sludge for Sludge Settling and Dewatering. J Civil Environ Eng 5: 191. doi:10.4172/2165-784X.1000191

Copyright: @ 2015 Nouha K, et al. This is an open-access article distributed under the terms of the Creative Commons Attribution License, which permits unrestricted use, distribution, and reproduction in any medium, provided the original author and source are credited. 
Citation: Nouha K, Hoang NV, Song Y, Tagi RD, Surampalli RY (2015) Characterization of Extracellular Polymeric Substances (Eps) Produced by Cloacibacterium normanense Isolated from Wastewater Sludge for Sludge Settling and Dewatering. J Civil Environ Eng 5: 191. doi:10.4172/2165-784X.1000191

Page 2 of 8

Isolated genomic DNA from the individual bacterial strains was subjected to PCR amplification of $16 \mathrm{~S}$ rDNA using universal primers [7]. Amplified products were purified using the Qiagen gel extraction kit and subsequently were sequenced [8]. The obtained $16 \mathrm{~S}$ rDNA gene sequences were submitted into the internet for similarity search.

\section{EPS production}

The sludge was first settled by gravity for $1 \mathrm{~h}$ and the settled (concentrated) sludge was collected by discarding the supernatant. Cloacibacterium normanense was inoculated in Tryptic soy broth (TSB) (100 mL sterilized TSB in $500 \mathrm{~mL}$ flask) and incubated for $48 \mathrm{~h}$. After $48 \mathrm{~h}$ incubation, the culture broth was used as inoculum to inoculate the sterilized $\left(12^{\circ} \mathrm{C}\right.$ for $\left.30 \mathrm{~min}\right)$ sludge $(25 \mathrm{~g}$ suspended solids-SS/L, $\mathrm{pH}$ $7,150 \mathrm{~mL}$ sludge in a $500 \mathrm{~mL}$ capacity flask). The flask was incubated in a shaking incubator at $180 \mathrm{rpm}$ and $30^{\circ} \mathrm{C}$ for $24 \mathrm{~h}$. This culture (with an approximate cell concentration $6.7 \times 10^{6}$ colony forming units$\mathrm{CFU} / \mathrm{mL})$ was used to inoculate $(3 \% \mathrm{v} / \mathrm{v})$ flask containing sterilized sludge ( $25 \mathrm{~g} / \mathrm{L} \mathrm{SS}, 150 \mathrm{~mL}$ sludge, $\mathrm{pH}$ 7). The flasks were incubated in a shaker at $180 \mathrm{rpm}$ and $30^{\circ} \mathrm{C}$ for $96 \mathrm{~h}$ for EPS production. Samples were withdrawn at each $12 \mathrm{~h}$ interval to measure the cell concentration, and each $24 \mathrm{~h}$ to measure the EPS concentration, flocculation activity and dewaterability. All the samples were serially diluted with saline solution and the cell concentration was measured as CFU employing standard agar-plate technique. All the measurements were carried out in triplicates and the average of the results was presented.

\section{Extraction of EPS}

After incubation, the fermented broth was centrifuged at $6000 \mathrm{~g}$, $4^{\circ} \mathrm{C}$ for $20 \mathrm{~min}$ to obtain supernatant (containing Slime- EPS (S-EPS) and the biomass pellet was re-suspended in deionized water to the initial volume (containing Capsular (C-EPS) $[9,10]$. To determine dry weight of S-EPS, the supernatant and ethanol $(95 \% \mathrm{v} / \mathrm{v})$ were mixed in 1:2 ratio and kept at $-20^{\circ} \mathrm{C}$ for overnight to precipitate the EPS. The precipitated EPS was collected (as a pellet) by centrifugation $\left(6000 \mathrm{~g}, 4^{\circ} \mathrm{C}, 20 \mathrm{~min}\right)$. The dry weight of the pellet corresponding to the EPS concentration (S-EPS) was measured by drying the precipitates at $60^{\circ} \mathrm{C}$ to a constant weight [9]. To determine dry weight of Capsular- EPS (C-EPS), the resuspended biomass pellet was first heated at $60^{\circ} \mathrm{Cin}$ a water bath for 30 min to release C-EPS into the liquid phase followed by centrifugation at $6000 \mathrm{~g}, 4^{\circ} \mathrm{Cfor} 20 \mathrm{~min}$ [11]. The supernatant containing C-EPS was used to measure dry weight using the same procedure as for S-EPS. The EPS concentration was estimated by the following formula:

$$
[\mathrm{EPS}](\mathrm{g} / \mathrm{L})=\frac{\mathrm{W} 2-\mathrm{W} 1}{\mathrm{~V}}
$$

Where, W1: Initial dry weight of the empty aluminium dish without a sample in $\mathrm{g}$

W2: End dry weight of the aluminum dish with dried sample in $g$

$\mathrm{V}$ : volume of the sample in $\mathrm{L}$

The total EPS (B-EPS) contained in the broth was calculated as sum of S-EPS and C-EPS.

All the measurements were carried out in triplicates and the average was presented.

\section{Chemical characterization of EPS}

After precipitation, the extracted C-EPS and S-EPS were dissolved in deionized water to the initial volume $(100 \mathrm{~mL}$ of the broth) and protein and carbohydrate content were measured. Protein was determined using bovine serum albumin as the standard [12]. The carbohydrate content was measured by Phenol-Sulfuric acid method [13] at 490 $\mathrm{nm}$ and glucose was used as the standard. The sample concentration was calculated by the linear equation between absorbance and concentration of the standard solution. All measurements were carried out in triplicates and the average was presented. The protein and carbohydrate ratios were calculated for B-EPS, C-EPS and S-EPS and the control sample (EPS extracted from sterilized sludge) by dividing the protein content by the carbohydrate content of each EPS.

\section{Flocculation activity of different EPS}

The flocculation activity of EPS was determined by jar test method [14] with minor modification. Kaolin solution $(5 \mathrm{~g} / \mathrm{L})$ was suspended in distilled water, $150 \mathrm{mg} / \mathrm{L}$ of $\mathrm{Ca}^{2+}$ was added to the kaolin suspension and $\mathrm{pH}$ was adjusted to 7 . The desired concentration of different types of EPS was added (in terms of volume of the sample range from 0.25 $\mathrm{mL}$ to $4 \mathrm{~mL}$ collected at different times of fermentation) to kaolin suspension and rapidly mixed at $180 \mathrm{rpm}$ for an initial $5 \mathrm{~min}$ then slowly mixed at $70 \mathrm{rpm}$ for an additional $30 \mathrm{~min}$. After mixing, samples were transferred to a $500 \mathrm{~mL}$ cylinder where they were allowed to settle for $30 \mathrm{~min}$. The supernatant of each sample was then collected to measure the turbidity using turbidimeter (Micro 100 turbidimeter, Scientific Inc.). Flocculation activity was measured using the formula $\left[100^{*}(\mathrm{~B}-\mathrm{A}) / \mathrm{B}\right]$ where ' $A$ ' is the turbidity of the sample (treated with S-EPS, C-EPS or B-EPS) and ' $B$ ' is the turbidity of the control sample (in which equal volume of EPS solution was replaced with distilled water). All the tests were conducted in triplicates and the average values were presented.

\section{Sludge volume index (SVI) study using S-EPS}

SVI was measured to determine the kaolin and sludge settling efficiency using the produced EPS. S-EPS was selected because of high concentration obtained during production and a very good flocculation activity observed in kaolin solution. Sludge samples ( $24 \mathrm{~h}$ stored at $4^{\circ} \mathrm{C}$ ) collected from the municipal wastewater treatment plant and pulp and paper industry sludge (PPS) was used. SVI was measured using different sludge SS concentrations ( $1 \mathrm{~g} / \mathrm{L}, 2 \mathrm{~g} / \mathrm{L}, 5 \mathrm{~g} / \mathrm{L}$ and $7 \mathrm{~g} / \mathrm{L})$. The well mixed sludge samples $(1 \mathrm{~L})$ were transferred into beakers followed by the addition of $600 \mathrm{mg} / \mathrm{L}$ of $\mathrm{Al}_{2}\left(\mathrm{SO}_{4}\right)_{3}$ as well as S-EPS and another beaker served as the control (no addition of EPS). After addition of EPS, the samples were mixed at $120 \mathrm{rpm}$ for first $5 \mathrm{~min}$ (which enables the biopolymers to mix and bring them in contact with the sludge particles) followed by mixing at $50 \mathrm{rpm}$ for $25 \mathrm{~min}$ (that enables flocs formation). Each mixed sludge sample was then transferred into 1 L graduated measuring cylinder for SVI measurement [15]. Sludge settling efficiency in each cylinder was monitored at 5, 10, 20 and 30 min. Similarly, the sample of kaolin was prepared; $150 \mathrm{mg}$ of $\mathrm{Ca}^{2+}$ was added in place of $600 \mathrm{mg} / \mathrm{L}$ of $\mathrm{Al}_{2}\left(\mathrm{SO}_{4}\right)_{3}$.

\section{Sludge dewaterability}

The capillary suction time (CST) was used to evaluate the dewaterability of the flocs in kaolin solution, MWWS and PPS using S-EPS produced by Cloacibacterium normanense. The CST of the control (without addition of the S-EPS) was also measured. The samples were prepared similar to SVI measurement. The sediment from each flocculation activity test was used to measure the CST by a CST instrument (Triton, Model 304 M, UK) [9]. A high value of CST usually implies a poor filterability and dewaterability.

\section{Results and Discussion}

\section{EPS production and characterization}

Growth and EPS production profiles of Cloacibacterium 
Citation: Nouha K, Hoang NV, Song Y, Tagi RD, Surampalli RY (2015) Characterization of Extracellular Polymeric Substances (Eps) Produced by Cloacibacterium normanense Isolated from Wastewater Sludge for Sludge Settling and Dewatering. J Civil Environ Eng 5: 191. doi:10.4172/2165-784X.1000191

Page 3 of 8

normanense sp. are presented in Figure 1. Exponential growth phase was observed between $12 \mathrm{~h}$ and $24 \mathrm{~h}$ of fermentation. The maximum cell concentration $\left(7.5 \times 10^{8} \mathrm{CFU} / \mathrm{mL}\right)$ reached at $48 \mathrm{~h}$. The concentration of B-EPS increased with the fermentation time and reached maximum $(13.3 \pm 0.9 \mathrm{~g} / \mathrm{L})$ at $48 \mathrm{~h}$ where the cell concentration was also maximum (Figure 1). The EPS concentration increased from 1.9 to $2.8 \mathrm{~g} / \mathrm{L}$ during lag phase (from 0 to $12 \mathrm{~h}$ ). The EPS production occurred mainly during the exponential growth phase but significant EPS production was also observed during declining phase i.e., between $36 \mathrm{~h}$ and $48 \mathrm{~h}$ of fermentation (Figure 1). The research of More et. al. [2] investigated the effect of fermentation time on EPS production in activated sludge and found that the EPS content was proportional to the bacterial growth. A decrease in B-EPS concentration (from 13.3 to $11.4 \mathrm{~g} / \mathrm{L}$ ) was observed between 48 and $96 \mathrm{~h}$. This decrease could be due to the fact that the bacteria may have consumed EPS when carbon limitation occurred in the medium. This phenomenon was also observed by other researchers using pure or mixed culture in sludge or synthetic medium $[2,16]$. According to More et. al. [17], the highest EPS concentration achieved was $3.4 \mathrm{~g} / \mathrm{L}$ in $72 \mathrm{~h}$ with sterilized sludge as a growth medium employing Serratia sp., which was much lower than the B-EPS concentration $(13.3 \mathrm{~g} / \mathrm{L})$ observed in the present study (Table 1). The EPS synthesis by microorganisms depends on the carbon and nitrogen availability in the culture medium. Most of the EPS producing

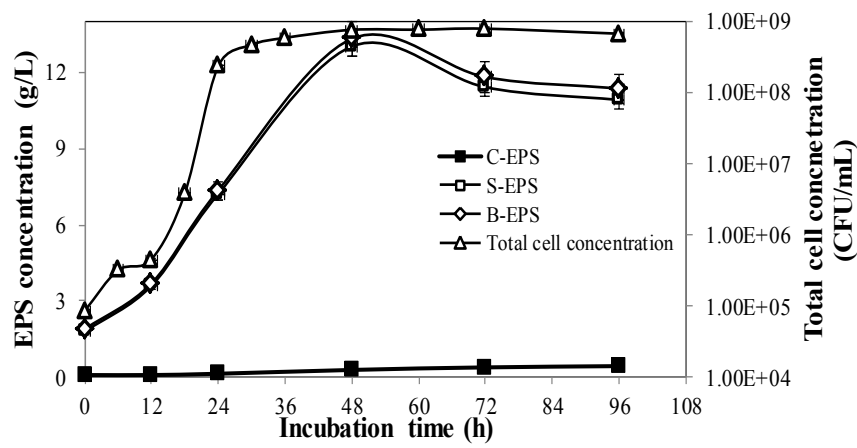

Figure 1: Growth and EPS (C-EPS and S-EPS) production profiles of Cloacibacterium normanense (NK6) using wastewater sludge as sole raw material. microorganisms use carbohydrates as their carbon and energy source and either ammonium salts or amino acids or both as their nitrogen source [18]. Therefore, the higher EPS concentration obtained in this work than those reported in the literature can be due to the fact that Cloacibactérium normanense strain may have a wider range of carbon and nitrogen utilization ability that eventually helped it to use available complex carbon and nitrogen sources present in sludge for its growth and EPS production.

\section{Protein and carbohydrate content}

Carbohydrate and protein content of S-EPS (LB-EPS) and C-EPS (TB-EPS) and their concentrations in the broth are presented in Figures 2a-2d. The total protein (TP) and the total carbohydrate (TC) content of the EPS and their concentration in the medium increased with fermentation time and reached maximum at $48 \mathrm{~h}$. The protein content (219.9 $\pm 5.3 \mathrm{mg} \mathrm{BSA} / \mathrm{g}$ of extracted EPS) and carbohydrate content $(128.5 \pm 6.3 \mathrm{mg}$ carbohydrate/g of extracted EPS) of S-EPS was higher than the protein content $(145.6 \pm 4.7 \mathrm{mg}$ of BSA/g of extracted EPS) and carbohydrate content $(104.0 \pm 5.5 \mathrm{mg}$ carbohydrate/g of extracted EPS) of C-EPS at $48 \mathrm{~h}$ fermentation. The protein and carbohydrate content of the EPS produced by the strain was higher than the control sample or the EPS extracted from the sterilized sludge $(72.9 \pm 1.1 \mathrm{mg}$ BSA/g of S-EPS and $28.0 \pm 2.1 \mathrm{mg}$ carbohydrate/g of S-EPS).

The protein and carbohydrate content of the EPS increased in exponential and declining phase (i.e., until $48 \mathrm{~h}$ ) followed by a decrease during the stationary phase (after $48 \mathrm{~h}$ ). The decrease in B-EPS concentration after $48 \mathrm{~h}$ (Figure 1) was due to degradation of proteins and carbohydrate of EPS by the bacterial strain. The stationary phase corresponded to the beginning of nutrient depletion in the medium and the accumulation of waste products limiting the growth. The culture grew exponentially followed by a slow growth until the maximum cell density was reached (at $48 \mathrm{~h}$ ), and eventually the growth ceased due to the cell lysis caused by the decrease in the integrity and stability of the cell surface. This process leads to a reduction or even complete cessation of extracellular product synthesis by microorganisms. Under this condition, the microorganism shift to use the carbohydrates and proteins of EPS to fulfill the demand of carbon and nitrogen sources. Zhang and Bishop [19] performed a comparative study to examine the

\begin{tabular}{|c|c|c|c|c|}
\hline Strains Name & Medium type & B-EPS (g/L) & $\begin{array}{c}\text { Fermentation condition } \\
\text { (shake flask) }\end{array}$ & References \\
\hline Bacillus sp.2 & Sludge (10 g/L) & 1.27 & $250 \mathrm{rpm}, 25^{\circ} \mathrm{C}, 72 \mathrm{~h}$ & More et al., [31] \\
\hline Bacillus sp.3 & Sludge (10 g/L) & 1.68 & $250 \mathrm{rpm}, 25^{\circ} \mathrm{C}, 72 \mathrm{~h}$ & More et al., [31] \\
\hline Bacillus sp.4 & Sludge (10 g/L) & 1.28 & $250 \mathrm{rpm}, 25^{\circ} \mathrm{C}, 72 \mathrm{~h}$ & More et al., [31] \\
\hline Bacillus sp.5 & Sludge (10 g/L) & 1.24 & $250 \mathrm{rpm}, 25^{\circ} \mathrm{C}, 72 \mathrm{~h}$ & More et al., [31] \\
\hline Bacillus sp. 6 & Sludge (10 g/L) & 1.45 & $250 \mathrm{rpm}, 25^{\circ} \mathrm{C}, 72 \mathrm{~h}$ & More et al., [31] \\
\hline Bacillus sp.7 & Sludge (10 g/L) & 1.56 & $250 \mathrm{rpm}, 25^{\circ} \mathrm{C}, 72 \mathrm{~h}$ & More et al., [31] \\
\hline Bacillus sp.8 & Sludge (10 g/L) & 1.65 & $250 \mathrm{rpm}, 25^{\circ} \mathrm{C}, 72 \mathrm{~h}$ & More et al., [31] \\
\hline Bacillus sp.9 & Sludge (10 g/L) & 1.23 & $250 \mathrm{rpm}, 25^{\circ} \mathrm{C}, 72 \mathrm{~h}$ & More et al., [31] \\
\hline Serratia sp.1 & Sludge (17 g/L) & 3.4 & $250 \mathrm{rpm}, 25^{\circ} \mathrm{C}, 72 \mathrm{~h}$ & More et al., [2] \\
\hline Pseudomonas & Mineral medium (25 g/L glucose, $\left.0.2 \mathrm{~g} / \mathrm{L} \mathrm{MgSO}_{4}\right)$ & 2.3 & $250 \mathrm{rpm}, 25^{\circ} \mathrm{C}, 72 \mathrm{~h}$ & Bala subramanian et al., [10] \\
\hline Serratia sp BS8 & Mineral medium $\left(25 \mathrm{~g} / \mathrm{L}\right.$ glucose, $\left.0.2 \mathrm{~g} / \mathrm{L} \mathrm{MgSO}_{4}\right)$ & 3 & $250 \mathrm{rpm}, 25^{\circ} \mathrm{C}, 72 \mathrm{~h}$ & Bala subramanian et al., [10] \\
\hline Bacillus sp BS9 & Mineral medium (25 g/L glucose, $\left.0.2 \mathrm{~g} / \mathrm{L} \mathrm{MgSO}_{4}\right)$ & 2.4 & $250 \mathrm{rpm}, 25^{\circ} \mathrm{C}, 72 \mathrm{~h}$ & Bala subramanian et al., [10] \\
\hline Yersinia sp BS11 & Mineral medium (25 g/L glucose, $0.2 \mathrm{~g} / \mathrm{L} \mathrm{MgSO}_{4}$ ) & 2.5 & $250 \mathrm{rpm}, 25^{\circ} \mathrm{C}, 72 \mathrm{~h}$ & Bala subramanian et al., [10] \\
\hline Microbacterium (BS15) & Mineral medium (25 g/L glucose, $\left.0.2 \mathrm{~g} / \mathrm{L} \mathrm{MgSO}_{4}\right)$ & 2.1 & $250 \mathrm{rpm}, 25^{\circ} \mathrm{C}, 72 \mathrm{~h}$ & Bala subramanian et al., [10] \\
\hline Staphylococcus aureus (A22) & Glycerol and Ethanol & 10.8 & $150 \mathrm{rpm}, 28^{\circ} \mathrm{C}, 48 \mathrm{~h}$ & Buthelezi et al., [32] \\
\hline $\begin{array}{c}\text { Pseudomonas } \\
\text { plecoglossicida (A14) }\end{array}$ & Glycerol and Ethanol & 8.3 & $150 \mathrm{rpm}, 28^{\circ} \mathrm{C}, 48 \mathrm{~h}$ & Buthelezi et al., [32] \\
\hline Cloacibacterium normanense & Sludge $(25 g / L)$ & 13.3 & $180 \mathrm{rpm}, 30^{\circ} \mathrm{C}, 48 \mathrm{~h}$ & Present work \\
\hline
\end{tabular}

Table 1: Production of B-EPS by different strains in present study and reported in the literature. 
Citation: Nouha K, Hoang NV, Song Y, Tagi RD, Surampalli RY (2015) Characterization of Extracellular Polymeric Substances (Eps) Produced by Cloacibacterium normanense Isolated from Wastewater Sludge for Sludge Settling and Dewatering. J Civil Environ Eng 5: 191. doi:10.4172/2165-784X.1000191

Page 4 of 8

biodegradability of EPS by microorganisms from the original biofilm (its own producers) and it was found that the cells consumed the newly produced EPS and microbial activity gradually stopped. Similarly, the present study also suggested that the EPS (protein and carbohydrate) could be used as a substrate. The protein content of the EPS was higher than the carbohydrate content (Figure 2) as observed by other researchers [20]. According to these authors, the protein was the main component and polysaccharides or carbohydrates were the secondary component of the EPS matrix in sludge. The bacterial strain used in this study was isolated from sludge and also grown in sterilized sludge (as raw material), therefore, EPS contained higher protein similar to that observed in activated sludge process. The total protein/total carbohydrate ratio of B-EPS varied from 1.48 to 1.85 with fermentation time (Figure 2e). This variation can explain the distinct nature of B-EPS
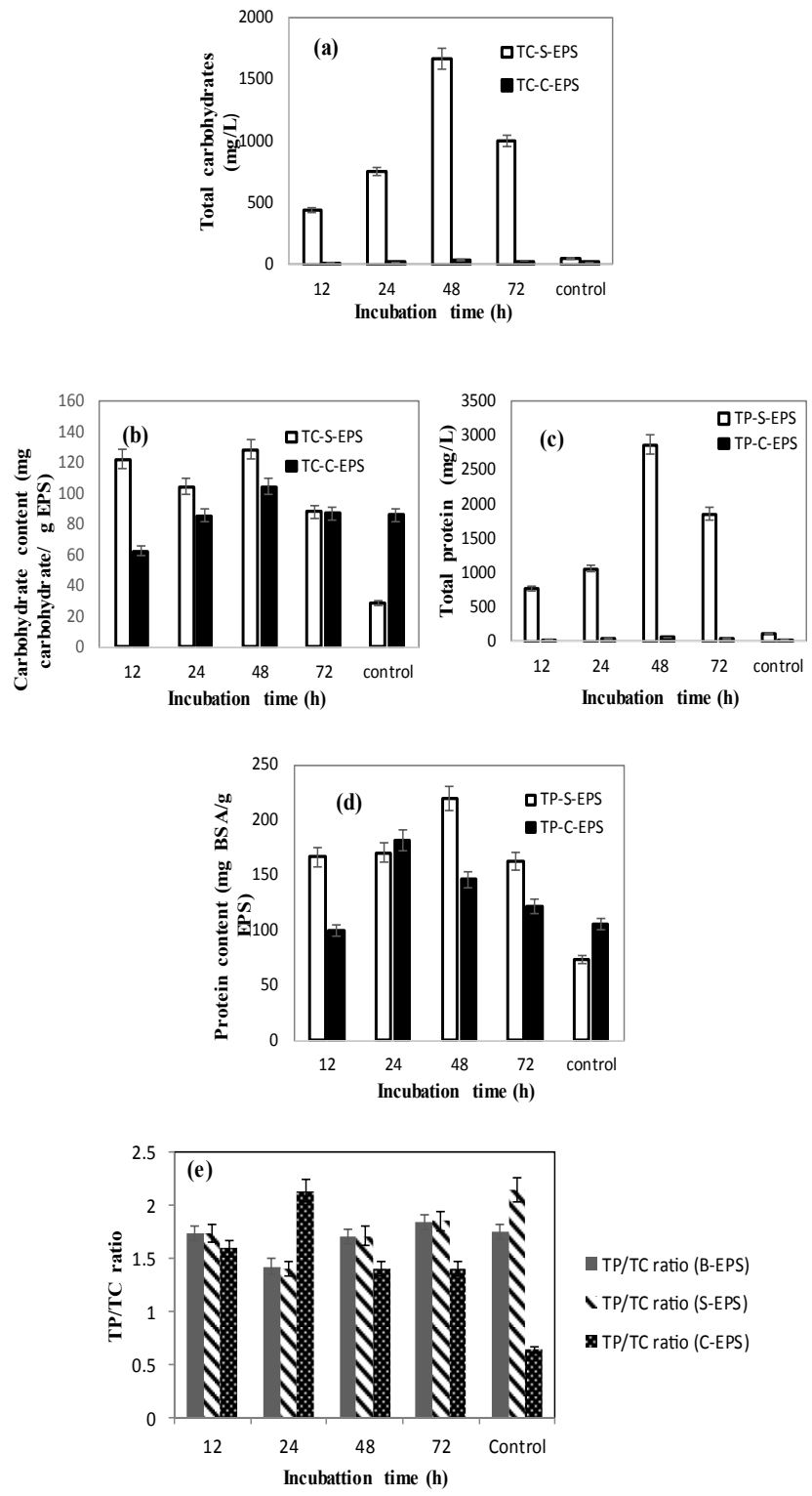

Figure 2: EPS composition in terms of protein and total carbohydrates at different incubation time: (a) Total carbohydrates (mg/L) in the medium; (b) Carbohydrate content of EPS (mg carbohydrate/g EPS), (c) Total protein mg/L in the medium; (d) Protein content of EPS (mg BSA/g EPS), (e) Total protein/ Total carbohydrates ratio of B-EPS, S-EPS and C-EPS.
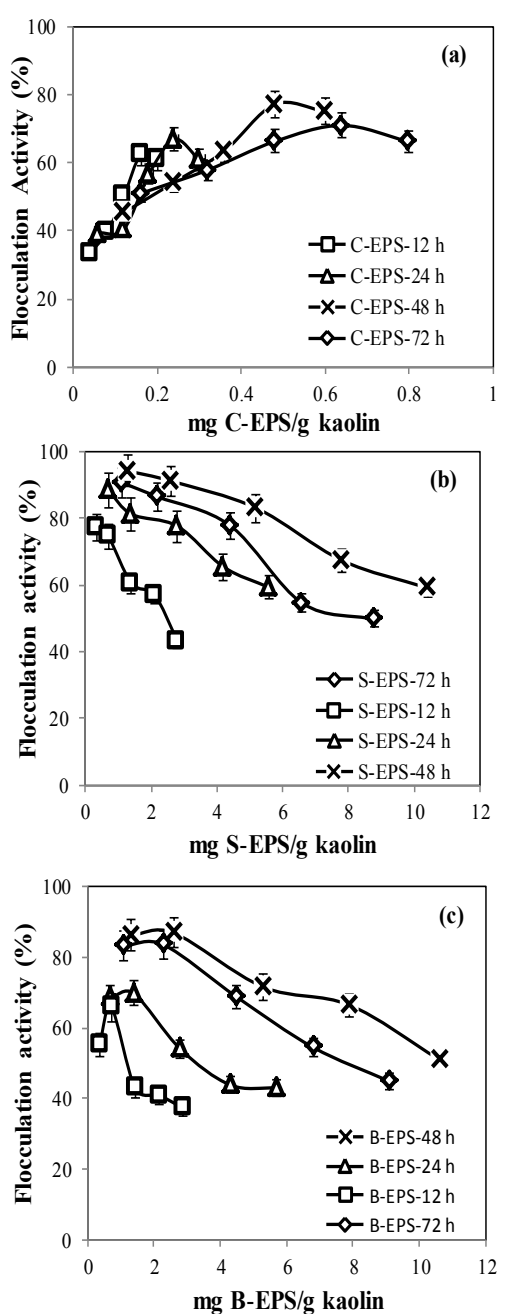

Figure 3: Effect of EPS concentration (mg EPS/g kaolin) on flocculation activity (a) C-EPS, (b) S-EPS and (c) B-EPS, respectively.

produced at different times of fermentation. The total protein/total carbohydrate ratio of B-EPS observed in this study was higher than reported in previous studies (0.34) in case of Serratia sp.1 [17] (Table 2). Thus, the EPS composition (i.e., protein and carbohydrate content) synthesised by the new strain was different than those reported by others [17]. In general, the composition of EPS is heterogeneous and varies based on many factors such as bacterial strain, growth phase, the EPS extraction method and different EPS production process parameters (temperature, $\mathrm{pH}$, agitation speed, cultivation time, medium composition, medium pre-treatment etc.) [16].

\section{Flocculation activity}

The results of flocculation activity (FA) of B-EPS, S-EPS and C-EPS are presented in Figure 3. The flocculation activity for B-EPS and $S$-EPS decreased with an increase in EPS concentration. The highest FA ( $48 \mathrm{~h}$ sample) was $94.2 \% \pm 1.3$ for S-EPS $(1.3 \pm 0.1 \mathrm{mg} \mathrm{S}$-EPS/g kaolin, Figure $3 \mathrm{~b}$ ), $86.8 \% \pm 3.5$ for B-EPS $(2.6 \pm 0.2 \mathrm{mg}$ B-EPS/g kaolin, Figure $3 \mathrm{c})$ and $79.4 \% \pm 1.4$ for C-EPS $(0.50 \pm 0.02 \mathrm{mg}$ C-EPS $/ \mathrm{g}$ of kaolin, Figure 3a). After attaining maximum value, a decrease in FA with EPS concentration was due to an over dosage of the polymer that caused re-suspension or instability of kaolin particles (flocs) leading to a high turbidity [21]. An equal volume of the samples 
Citation: Nouha K, Hoang NV, Song Y, Tagi RD, Surampalli RY (2015) Characterization of Extracellular Polymeric Substances (Eps) Produced by Cloacibacterium normanense Isolated from Wastewater Sludge for Sludge Settling and Dewatering. J Civil Environ Eng 5: 191. doi:10.4172/2165-784X.1000191

Page 5 of 8

taken at different fermentation time exhibited different FA because of the variation in EPS concentration (Figure 3). The maximum FA of $86.8 \% \pm 3.5$ using $2.6 \pm 0.2 \mathrm{mg}$ B-EPS/g Kaolin observed in the present study was higher than the maximum FA (79.1\%) obtained using 0.7 mg B-EPS/g kaolin in case of Serratia sp.1[17] Higher FA achieved using S-EPS in the present study is due to the specific structure of EPS. The difference in results of FA for different types of EPS (B-EPS, S-EPS and C-EPS) could be due to the presence of diverse nature of proteins and carbohydrates. Proteins and carbohydrates are complex materials and may contain structurally different components (or functional groups), which may change with fermentation time (Figure 2) and thus affecting the FA of the EPS [22]. The protein content and type could play a dominant role in flocculation through hydrophobic interactions and polyvalent cations bridging, which increases the floc binding strength and hence enhancing the stability of the biopolymer network. Moreover, the hydrogen bonding capacity of carbohydrates also helps in flocculation [23]. The flocculation activity of B-EPS was lower than S-EPS. The difference in flocculation activity between S-EPS and B-EPS could be due to the fact that B-EPS contains both the C-EPS and S-EPS. C-EPS could hamper the efficiency of the S-EPS when two EPS were present together in the broth. C-EPS contained abundant hydrophilic compounds (hydroxyl group) that interacted with molecules of water hindering the combination of S-EPS (which contain hydrophobic compounds) with C-EPS or other hydrophilic particles [24]. Moreover, B-EPS have the negative surface charge and contains both EPS (S-EPS \& C-EPS) as well as other substances such as colloidal and residual matter (cells, organic and inorganic material etc.). Increase in volume of the B-EPS in kaolin solution (the assay solution) also increases the negative surface charge due to increase in colloidal content, which could destabilize the flocs and thus decreases the flocculation activity. The charge of EPS can affect the flocculation activity. The zeta potential of S-EPS $(-47.9 \pm 0.4 \mathrm{mV})$ is higher than that of C-EPS $(-62.7 \pm 0.9 \mathrm{mV})$ and that of B-EPS $(-71.9 \pm 1.2 \mathrm{mV})$. The higher zeta potential of S-EPS implies the degree of repulsion between the EPS molecules is less, which tend to improve the bio-flocculation. The zeta potential of fresh sludge was $-89.1 \pm 0.8 \mathrm{mV}$, with the addition of $\mathrm{Ca}^{2+}$, zeta potential increased to $-45.9 \pm 1.4 \mathrm{mV}$. The zeta potential of kaolin suspensions $(5 \mathrm{~g} / \mathrm{L})$ without $\mathrm{Ca}^{2+}$ and EPS was $-38.4 \pm 1.5$ $\mathrm{mV}$, and it was increased to $-17.1 \pm 0.5 \mathrm{mV}$ by the addition of 150 $\mathrm{mg}$ of $\mathrm{Ca}^{2+} / \mathrm{L}$. The addition of EPS, after $\mathrm{Ca}^{2+}$, to kaolin suspension had very small change in the charge. Therefore, charge neutralization of the kaolin particles was achieved mostly by the addition of $\mathrm{Ca}^{2+}$. However, the EPS addition after $\mathrm{Ca}^{2+}$ revealed high flocculation activity and enhanced dewaterability (discussed in the next section). These results suggest that the specific interactions of EPS and calcium with kaolin particles can be supported by adsorption and bridging mechanism.

\section{Sludge settling}

S-EPS exhibited better kaolin FA than other types of EPS. Therefore, S-EPS was used to estimate the sludge settling characteristics of pulp and paper industry activated sludge (PPS) (Figure 4) and municipal wastewater secondary sludge (MWWS) (Figure 5) at different suspended solids concentrations $(1,2,5$ and $7 \mathrm{~g} / \mathrm{L})$. The SVI was below $100 \pm 1.5 \mathrm{~mL} / \mathrm{g}$ after $30 \mathrm{~min}$ settling. For a good sludge settling, SVI $\leq 100$ is required (APHA, 2005). The addition of cations $(600 \mathrm{mg} / \mathrm{L}$ of $\left.\mathrm{Al}_{2}\left(\mathrm{SO}_{4}\right)_{3}\right)$ without EPS slightly improved the SVI value of the control samples (SVI decreased from 140 to $110 \mathrm{~mL} / \mathrm{g}$ in case of PPS with $7 \mathrm{~g}$ SS /L; and SVI decreased from 200 to $40 \mathrm{~mL} / \mathrm{g}$ in case of MWWS with 5 $\mathrm{g} \mathrm{SS} / \mathrm{L}$ ). The reduction of SVI in control is due to the coagulation effect of $\mathrm{Al}_{2}\left(\mathrm{SO}_{4}\right)_{3}$ in combinations with the native EPS of sludge $(1.6 \pm 0.3 \mathrm{~g}$ $\mathrm{EPS} / \mathrm{L}$ in fresh PPS and of $1.2 \pm 0.5 \mathrm{~g}$ EPS/L in MWWS). Further, SVI
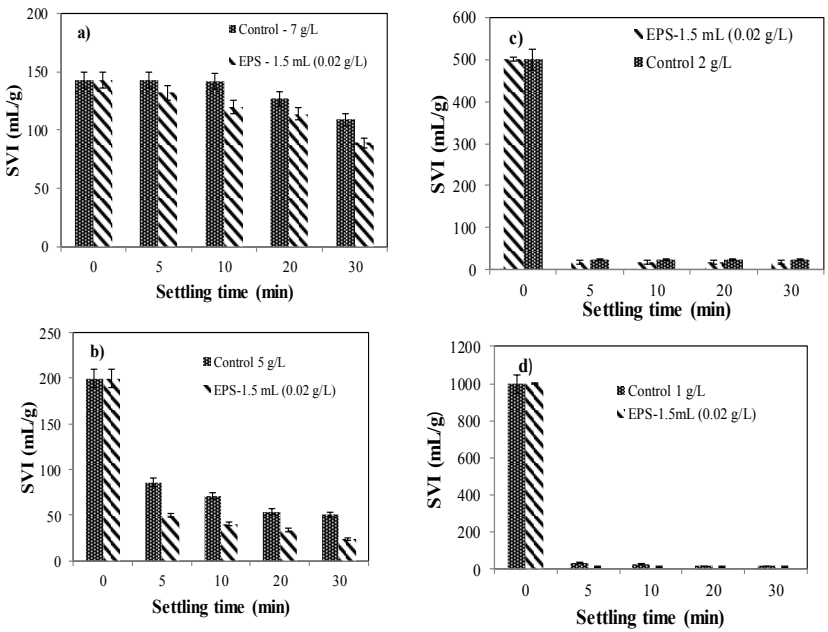

Figure 4: Effect of EPS on pulp and paper sludge settling (SVI) at different solids (SS) concentrations; (a) SS: $7 \mathrm{~g} / \mathrm{L}$, (b) SS: 5 g/L, (c) SS: $2 \mathrm{~g} / \mathrm{L}$ and (d) SS: $1 \mathrm{~g} / \mathrm{L}$.
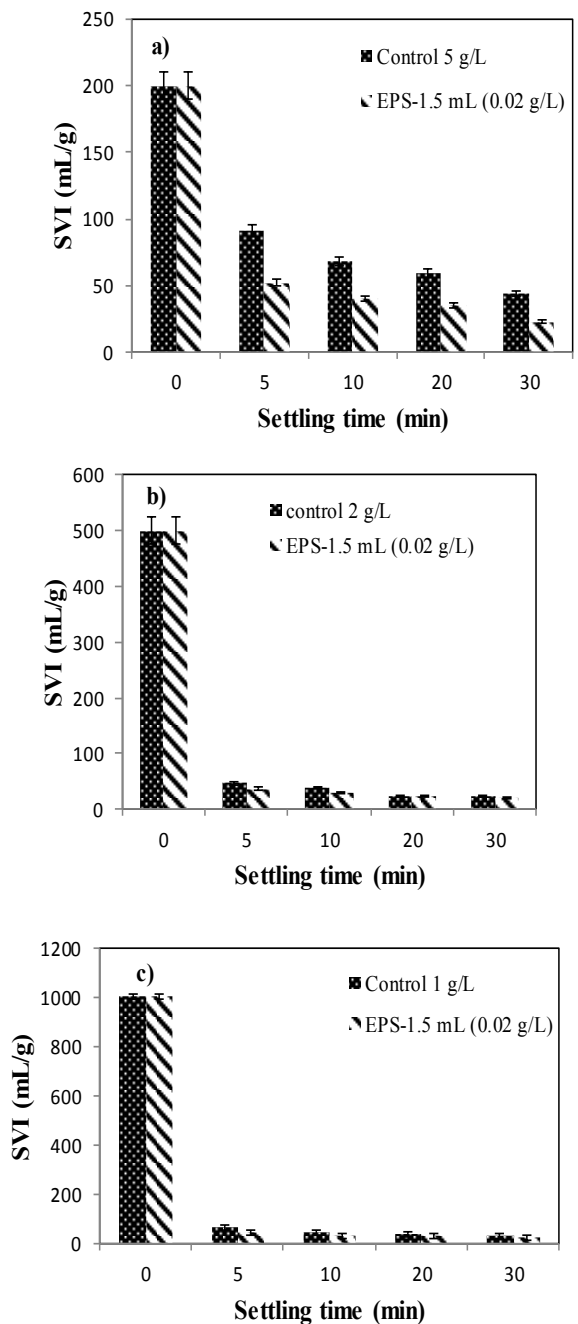

Figure 5: Effect of EPS on MWWS settling (SVI) at different solids concentrations of (a) $5 \mathrm{~g} / \mathrm{L}$ (b) $2 \mathrm{~g} / \mathrm{L}$ (c) $1 \mathrm{~g} / \mathrm{L}$. 
Citation: Nouha K, Hoang NV, Song Y, Tagi RD, Surampalli RY (2015) Characterization of Extracellular Polymeric Substances (Eps) Produced by Cloacibacterium normanense Isolated from Wastewater Sludge for Sludge Settling and Dewatering. J Civil Environ Eng 5: 191. doi:10.4172/2165-784X.1000191

Page 6 of 8

\begin{tabular}{|c|c|c|c|c|c|c|}
\hline Strains & B-EPS (g/L) & Medium & TC (\%) ${ }^{a}$ & TP $(\%)^{b}$ & Car/Protein ratioc & References \\
\hline Bacillus sp.7 & 1.6 & Sludge $(10 \mathrm{~g} / \mathrm{L})$ & & & 0.89 & More et al., [31] \\
\hline Serratia sp.1 & 3.4 & Sludge $(25 \mathrm{~g} / \mathrm{L})$ & 12.3 & 40 & 0.3 & Bezawada et al., [27] \\
\hline Yersiniasp.1 (BS11) & 2.5 & Synthetic medium & 6 & 4.1 & 1.46 & Bala subramanian et al., [10] \\
\hline Serratia sp.1 (BS8) & 3 & Synthetic medium & 5.2 & 2.8 & 1.89 & Bala subramanian et al., [10] \\
\hline Cloacibacterium Normanense & 13.3 & Sludge (25 g/L) & 12.7 & 21.8 & 0.58 & Present study \\
\hline
\end{tabular}

Note: ${ }^{\mathrm{T} T C}$ - total carbohydrate; ${ }^{\mathrm{T} T P}$ - total protein. ${ }^{\mathrm{C}} \mathrm{Car}-$ carbohydrates.

Table 2. Characterization of extracted EPS in terms of total protein and carbohydrates.

\begin{tabular}{|c|c|c|c|c|c|c|c|c|c|c|c|}
\hline \multirow[t]{2}{*}{ Strains } & \multirow[t]{2}{*}{$\begin{array}{l}\text { B-EPS } \\
\text { (g/L) }\end{array}$} & \multirow[t]{2}{*}{$\begin{array}{c}\text { Raw } \\
\text { material }\end{array}$} & \multicolumn{2}{|c|}{ Flocculation activity } & \multicolumn{2}{|c|}{$\begin{array}{c}\text { Dewaterability of } \\
\text { Kaolin }\end{array}$} & \multicolumn{2}{|c|}{ Dewaterability of sludge } & \multicolumn{2}{|c|}{ Settling of Sludge } & \multirow[t]{2}{*}{ References } \\
\hline & & & FA (\%) & $\begin{array}{l}\text { EPS Added } \\
\text { (S-EPS } \\
\mathrm{mg} / \mathrm{g} \\
\mathrm{kaolin} \text { ) }\end{array}$ & CST(\%) & $\begin{array}{c}\text { EPS added, } \\
\text { (S-EPS } \mathrm{mg} / \mathrm{g} \\
\text { Kaolin) }\end{array}$ & $\begin{array}{l}\text { CST (\%) } \\
\text { (MWWS) }\end{array}$ & $\begin{array}{l}\text { EPS Added } \\
\text { (S-EPS } \mathrm{mg} / \mathrm{g} \\
\text { SS) }\end{array}$ & $\begin{array}{c}\mathrm{SVI}(\mathrm{mL} / \mathrm{g}) \\
\text { (MWWS) }\end{array}$ & $\begin{array}{c}\text { EPS Added } \\
\text { (S-EPS } \\
\mathrm{mg} / \mathrm{g} \mathrm{SS} \text { ) }\end{array}$ & \\
\hline Bacillus sp.7 & 1.6 & $\begin{array}{l}\text { Sludge } \\
(10 \mathrm{~g} / \mathrm{L})\end{array}$ & 81.7 & $1.12-2.7$ & 65 & $1.12-2.7$ & - & - & - & - & More et al., [31] \\
\hline Serratia sp.1 & 3.4 & $\begin{array}{l}\text { Sludge } \\
(25 \mathrm{~g} / \mathrm{L})\end{array}$ & 79.1 & 2.7 & 34.7 & 2.7 & - & - & - & - & More et al., [2] \\
\hline BS11 & 2.5 & $\begin{array}{l}\text { Synthetic } \\
\text { medium }\end{array}$ & 85.7 & 250 & - & 250 & 77.38 & 250 & 63 & 250 & $\begin{array}{l}\text { Bala subramanian } \\
\text { et al., [10] }\end{array}$ \\
\hline BS8 & 3 & $\begin{array}{l}\text { Synthetic } \\
\text { medium }\end{array}$ & 81.4 & 400 & - & 400 & 63.6 & 400 & 60 & 400 & $\begin{array}{c}\text { Bala subramanian } \\
\text { et al., [10] }\end{array}$ \\
\hline $\begin{array}{c}\text { Cloacibacterium } \\
\text { Normanense }\end{array}$ & 13.3 & $\begin{array}{c}\text { Sludge (25 } \\
\mathrm{g} / \mathrm{L})\end{array}$ & 94.2 & 1.3 & 59.9 & 5.2 & 37.6 & 9.75 & 20 & 3.9 & Present Study \\
\hline
\end{tabular}

Table 3: Comparison of flocculation activity, dewaterability and settling results.

was substantially improved by the addition of S-EPS (Figures 4 and 5). The SVI varies with the concentration of sludge SS, the type of sludge and the added concentration of S-EPS. In this study, different volumes of S-EPS were used to obtain different concentrations of EPS. It was found that $1.5 \mathrm{~mL}$ (or $0.02 \pm 0.01 \mathrm{~g} \mathrm{~S}$-EPS/L) of S-EPS revealed the best settling compared to a lower or higher concentration of the EPS. An increase in SVI value with EPS concentration greater than $0.02 \mathrm{~g} / \mathrm{L}$ ( 4 $\mathrm{mg}$ of S-EPS/g SS) was due to bound water increase into the aggregates, which produced highly porous flocs with low density [25]. Therefore, $0.02 \mathrm{~g} / \mathrm{L}$ S-EPS concentration was used to evaluate the variation of SVI at different SS concentrations. In case of PPS at SS $5 \mathrm{~g} / \mathrm{L}$, the lowest SVI value was $20 \pm 2 \mathrm{~mL} / \mathrm{g}$ with an optimum concentration of EPS $(1.5 \mathrm{~mL}$ or $0.02 \pm 0.01 \mathrm{~g} \mathrm{~S}$-EPS/L) and SVI of the control was $50 \pm 1$ $\mathrm{mL} / \mathrm{g}$. In case of MWWS at SS $5 \mathrm{~g} / \mathrm{L}$ and same concentration of the EPS, the SVI value $(20 \pm 2 \mathrm{~mL} / \mathrm{g})$ was similar to the SVI value of the PPS; however, SVI of the control was different $(40 \pm 2.5 \mathrm{~mL} / \mathrm{g})$. The different SVI of the control of PPS and MWWS could be because of the difference of organic matter present in different sludges, which affected the bioflocculation process. These results of SVI are better than those reported by Bala subramanian et. al. [10] (Table 3). In case of MWWS at SS $5 \mathrm{~g} / \mathrm{L}$, the lowest SVI was $60 \mathrm{~mL} / \mathrm{g}$ using S-EPS concentration of 2 $\mathrm{g} / \mathrm{L}$ (400 mg S-EPS/g SS) produced by the bacterial strain BS8 (Serratia sp.). Thus, the biopolymer produced by Cloacibacterium normanense strain (present study) was more effective in sludge settling at a very low concentration $(0.02 \mathrm{~g} / \mathrm{L}$ or $4.0 \pm 0.5 \mathrm{mg} \mathrm{S}$-EPS $/ \mathrm{g} \mathrm{SS})$ than the biopolymer produced by BS8 (Serratia sp.) [10]. The carbohydrate and protein contents of EPS were found to have a positive relationship with SVI [20]. The protein probably is more important than the carbohydrates; the high protein content of S-EPS would improve bioflocculation and settling property of activated sludge [26]. The higher protein content of the EPS produced by the present strain than that produced by Serratia sp. [17] could explain the lower value of SVI at lower concentration of S-EPS.

\section{Sludge dewaterability}

The minimum CST value of kaolin solution was $23.2 \pm 0.3 \mathrm{~s}(\Delta \mathrm{CST}$
$=16.7 \pm 0.4 \mathrm{~s}), 21.4 \pm 2.4 \mathrm{~s}(\Delta \mathrm{CST}=18.5 \pm 0.9 \mathrm{~s})$ and $22.7 \pm 0.7 \mathrm{~s}(\Delta \mathrm{CST}=$ $17.2 \pm 1.2 \mathrm{~s}$ ) with the addition of $2.6 \pm 0.2 \mathrm{mg} \mathrm{B}-\mathrm{EPS} / \mathrm{g}$ Kaolin, $1.3 \pm 0.1$ $\mathrm{mg} \mathrm{S}$-EPS/g Kaolin and $0.03 \pm 0.01 \mathrm{mg}$ C-EPS/g Kaolin, respectively. These values were lower compared to the control sample (without addition of EPS) $(39.9 \pm 0.8 \mathrm{~s})$. This result is better than that reported by other researchers [27] who found that the minimum CST value of the kaolin solution was $23.7 \mathrm{~s}(\Delta \mathrm{CST}=6.8 \mathrm{~s})$ and $24.5 \mathrm{~s}(\Delta \mathrm{CST}=8.1$ s) with the addition of B-EPS and S-EPS, respectively with a dose of $3.44 \pm 0.05 \mathrm{~B}$-EPS/g kaolin and $1.70 \pm 0.05 \mathrm{~S}$-EPS/g kaolin, respectively. However, the required CST value for a good dewaterability is $20 \mathrm{~s}$ [10]. The CST value increased with the increase in EPS concentration. The CST value did not vary much (changed from $21.4 \pm 0.3 \mathrm{~s}$ to $21.9 \pm 0.1$ s) by increasing the S-EPS concentration from $1.3 \pm 0.1 \mathrm{mg} \mathrm{S}$-EPS $/ \mathrm{g}$ Kaolin to $3.9 \pm 0.5 \mathrm{mg}$ S-EPS/g Kaolin; whereas the CST value increased from $23.2 \pm 0.2 \mathrm{~s}$ to $29.4 \pm 0.3 \mathrm{~s}$ by increasing the B-EPS concentration from $2.6 \pm 0.2 \mathrm{mg} \mathrm{B}-\mathrm{EPS} / \mathrm{g}$ kaolin to $4.0 \pm 0.5 \mathrm{mg} \mathrm{B}-\mathrm{EPS} / \mathrm{g}$ kaolin. Thus, S-EPS was more efficient than B-EPS. Poor dewaterability was observed in case of C-EPS. The CST value increased from $22.7 \pm 0.5$ $\mathrm{s}$ to $26.2 \pm 0.4 \mathrm{~s}$ by increasing C-EPS concentration from $0.03 \pm 0.01$ $\mathrm{mg}$ C-EPS/g Kaolin to $0.09 \pm 0.02 \mathrm{mg}$ C-EPS/g Kaolin. Excessive EPS concentration might deteriorate cell attachment and weaken the floc structure, which in turn lead to a poor sludge settling and dewaterability [11]. In this work, S-EPS and B-EPS exhibited higher dewaterability than C-EPS in kaolin solution. This was due to the formation of bigger flocs caused by higher protein content of S-EPS and B-EPS (sample collected at $48 \mathrm{hr}$ ) compared to C-EPS. It was widely reported that an increase of EPS concentration would lower the sludge dewaterability [25,28]. Houghton et. al. [29] found that an increase in dewaterability with EPS (at low concentration of EPS) was due to the enhancement of flocculation. The increase in flocculation resulted in an increase in floc size and thus improved the sludge dewaterability. In the present case, an increase in EPS concentration above $1.3 \pm 0.1 \mathrm{mg}$ EPS/g of kaolin increased the amount of surface bound water by EPS, and thus decreased the kaolin dewatrability. Contrary to these findings, Jin et. al. [30] found that the concentration of the individual polymers and 
Citation: Nouha K, Hoang NV, Song Y, Tagi RD, Surampalli RY (2015) Characterization of Extracellular Polymeric Substances (Eps) Produced by Cloacibacterium normanense Isolated from Wastewater Sludge for Sludge Settling and Dewatering. J Civil Environ Eng 5: 191. doi:10.4172/2165-784X.1000191

Page 7 of 8

total EPS had negative correlations with CST. The results obtained for dewaterability on municipal and pulp and paper secondary sludge using S-EPS were presented (Figures $6 \mathrm{a}$ and $6 \mathrm{~b}$ ). At $2 \mathrm{~g} / \mathrm{L}$ SS of MWWS, the CST value was decreased from $130 \pm 2 \mathrm{~s}$ (in the control sample) to $81 \pm 1 \mathrm{~s}$ with the addition of $0.02 \pm 0.01 \mathrm{~g} / \mathrm{L}$ of S-EPS (Figure $6 \mathrm{~b}$ ). A good dewaterability of PPS was achieved at $5 \mathrm{~g} / \mathrm{L}$ SS; the CST value decreased from $10.0 \pm 0.4 \mathrm{~s}$ (control) to $8.0 \pm 0.1 \mathrm{~s}$ (with S-EPS dose of $0.02 \pm 0.01 \mathrm{~g} / \mathrm{L}$ ) (Figure 6a). The EPS produced by Cloacibacterium normanense strain (this work) was more effective in lowering the CST value than the EPS present in sludge $(1.6 \mathrm{~g} / \mathrm{L}$ of PPS and $1.2 \mathrm{~g} / \mathrm{L}$ MWWS). In this work, reduction in CST was more effective at low EPS concentration compared to the results reported by Bala subramanian et. al. [10], where the CST value decreased from $130 \mathrm{~s}$ (control) to 36.4 $\mathrm{s}$ after addition of $400 \mathrm{mg} \mathrm{S-EPS} \mathrm{/g} \mathrm{SS} \mathrm{produced} \mathrm{by} \mathrm{BS8} \mathrm{strain} \mathrm{(Table}$ 3). The dewaterability improvement was higher in MWWS than in PPS (Figure 6). This might be due to the difference in characteristics of organic matter in MWWS and PPS as well as the structure of protein and carbohydrate of EPS and their content in sludge [31,32].

\section{Conclusions}

High concentration $(13 \pm 0.8 \mathrm{~g} / \mathrm{L}$ of S-EPS and $0.3 \pm 0.1 \mathrm{~g} / \mathrm{L}$ C-EPS) of extracellular polymeric substances (EPSs) was produced by Cloacibacterium normanense in sterilized sludge with $25 \mathrm{~g} / \mathrm{L}$ suspended solids. EPS combined with $\mathrm{Ca}^{2+}$ demonstrated to be a good bioflocculant. Slime EPS exhibited higher flocculation activity (94.2\%) and better dewaterability (59.9\%) compared to the capsular EPS and
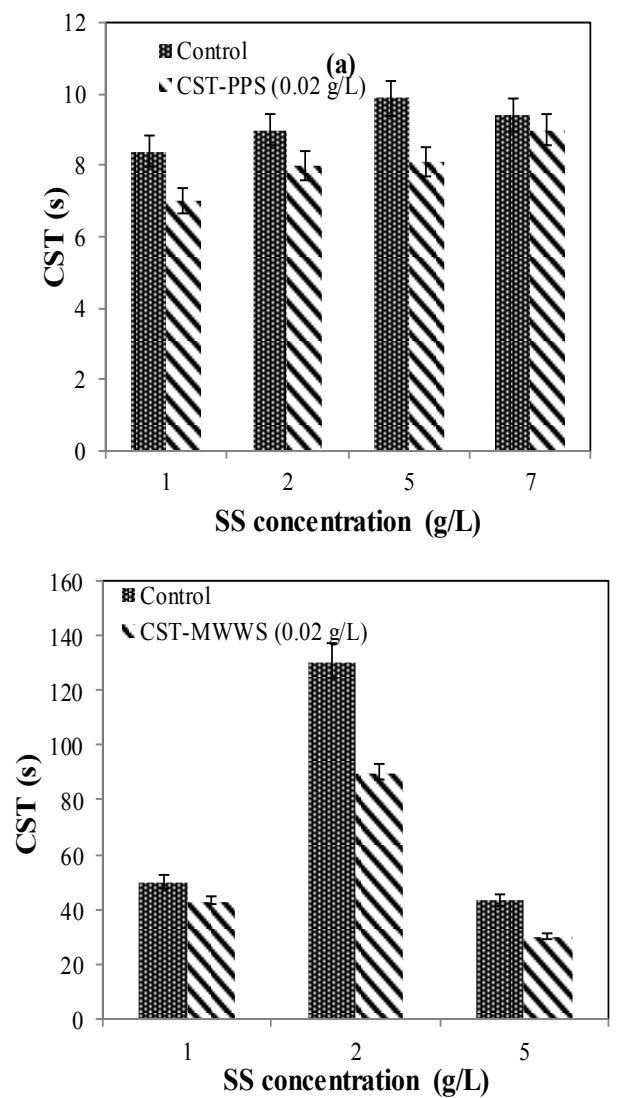

Figure 6: Effect of S-EPS on sludge dewaterability at different sludge suspended solids concentration; (a) pulp and paper sludge and (b) municipal wastewater sludge. the broth EPS in kaolin solution. The maximum dewaterability of municipal wastewater sludge (with suspended solids $2 \mathrm{~g} / \mathrm{L}$ ) achieved wad $37.6 \%$ with the use of $0.02 \pm 0.01 \mathrm{~g} / \mathrm{L}$ of slime-EPS and $600 \mathrm{mg} / \mathrm{L}$ of $\mathrm{Al}_{2}\left(\mathrm{SO}_{4}\right)_{3}$. The study showed a promising approach of new isolated strain, which produced high concentration of EPS in sludge with high flocculation activity as well as good settling.

\section{Acknowledgements}

Sincere thanks to the Natural Sciences and Engineering Research Council of Canada (Grant A 4984, Canada Research Chair) for financial support. The views and opinions expressed in this paper are those of the authors.

\section{References}

1. Tyagi RD, Sikati-Foko V, Barnabe S, Vidyarthi AS, Valéro JR et. al. (2002) Simultaneous production of biopesticide and alkaline proteases by Bacillus thuringiensis using sewage sludge as a raw material. Water Sci Technol 46: 247-254.

2. More TT, Mahmoudi A, Yan S, Tyagi RD (2014) Extracellular polymeric substances production kinetics of 13 sludge isolates using wastewater sludge as raw material and its flocculation potential. Environ Technol 1-14.

3. Garnier C, Gorner T, Lartiges BS, Abdelouhab S, Donato P (2005) Characterization of activated sludge exopolymers from various origins: A combined size-exclusion chromatography and infrared microscopy study. Water Res 39: 3044-3054.

4. Flemming HC, Wingender J (2001) Relevance of microbial extracellular polymeric substances (EPS)-Part I: structural and ecological aspects. Water sci Technol 43: 1-8.

5. Nielsen PH, Jahn A (1999) Extraction of EPS. In: Microbial Extracellular Polymeric Substances: Characterization, Structure and Function. Wingender J, Neu TR, Flemming HC (Eds). Springer-Verlag, Berlin, Germany, 50-72.

6. Keene L, Lindberg B (1983) Bacterial polysaccharides. In: The Polysaccharides Aspinall, G.O. 287-363.

7. Weisburg WG, Barns SM, Pelletier DA, Lane DJ (1991) 16S ribosomal DNA amplification for phylogenetic study. J Bacteriol 173: 697-703.

8. Bala subramanian S, Yan S, Tyagi RD, Surampalli RY (2007) Characterization of Extracellular Polymeric Substances (EPS) Extracted from both Sludge and Pure Bacterial Strains Isolated from Wastewater Sludge for Sludge Dewatering IWA conference on - Moving Forward, Wastewater Biosolids Sustainability: Technical, Managerial, and Public Synergy. Moncton, NB, Canada.

9. APHA (2005) Standard methods for the examination of water and wastewater $\left(21^{\text {st }}\right.$ eds. ). American Public Health Association, Washington, DC.

10. Bala subramanian S, Yan S, Tyagi RD, Surampalli RY (2010) Extracellular polymeric substances (EPS) producing bacterial strains of municipal wastewater sludge: isolation, molecular identification, EPS characterization and performance for sludge settling and dewatering. Water Res 44: 2253-2266.

11. Li XY, Yang SF (2007) Influence of loosely bound extracellular polymeric substances (EPS) on the flocculation, sedimentation and dewaterability of activated sludge. Water Res 41: 1022-1030.

12. Bradford MM (1976) A rapid and sensitive method for the quantitation of microgram quantities of protein utilizing the principle of protein-dye binding. Anal Biochem 72: 248-254.

13. DuBois M, Gilles KA, Hamilton JK, Rebers PA, Smith F (1956) Colorimetric method for determination of sugars and related substances. Analytical Chemistry 28: 35-356.

14. Kurane R, Takeda K, Suzuki T (1986) Screening and characteristics of microbial flocculants. Agric Biol Chem 50: 2301-2307.

15. Bala subramanian S, Yan S, Tyagi RD, Surampalli RY (2008) A new, pellet forming fungal strain: Its isolation, molecular identification, and performance for simultaneous sludge solids reduction, flocculation, and dewatering. Water Environ Res 809: 840-852.

16. Sheng GP, Yu HQ, Li XY (2010) Extracellular polymeric substances (EPS) of microbial aggregates in biological wastewater treatment systems: a review. Biotechnol Adv 28: 882-894.

17. More TT, Yan S, Hoang NV, Tyagi RD, Surampalli RY (2012)b Bacteria polymer production using pre-treated sludge as raw material and its flocculation and dewatering potential. Bioresour Technol 121: 425-431. 
Citation: Nouha K, Hoang NV, Song Y, Tagi RD, Surampalli RY (2015) Characterization of Extracellular Polymeric Substances (Eps) Produced by Cloacibacterium normanense Isolated from Wastewater Sludge for Sludge Settling and Dewatering. J Civil Environ Eng 5: 191. doi:10.4172/2165-784X.1000191

18. Gandhi HP, Ray RM, Patel RM (1997) Exopolymer production by Bacillus species. Carbohydr. Polym 34: 323-327.

19. Zhang X, Bishop PL (2003) Biodegradability of biofilm extracellular polymeric substances. Chemosphere 50: 63-69.

20. Bura R, Cheung M, Liao B, Finlayson J, Lee BC et al. (1998) Composition of extracellular polymeric substances in the activated sludge floc matrix. Water Sci Technol 37: 325-333.

21. Dermlim W, Prasertsan P, Doelle H (1999) Screening and characterization of bioflocculant produced by isolated Klebsiella Sp. Appl Microbiol Biotechnol 52 698-703.

22. Higgins MJ, Novak JT (1997) Characterization of exocellular protein and its role in bioflocculation. J Environ Eng 123: 479-485

23. Dignac MF, Urbain V, Rybacki D, Bruchet A, Snidaro D (1998) Chemical description of extracellular polymers: implication on activated sludge floc structure. Water Sci Technol 38: 45-53.

24. Yu T, Lei Z, Sun De-Zhi (2006) Functions and behaviors of activated sludge extracellular polymeric substances (EPS): a promising environmental interest. J Environ Sci 18: 420-427.

25. Yang SF, Li XY (2009) Influences of extracellular polymeric substances (EPS) on the characteristics of activated sludge under non-steady-state conditions. Process Biochem 44: 91-96.
26. Hoa PT, Nair L, Visvanathan C (2003) The effect of nutrients on extracellular polymeric substance production and its influence on sludge properties. Water SA 29: $437-442$

27. Bezawada J, Hoang NV, More TT, Yan S, Tyagi RD, Surampalli RY (2013) Production of extracellular polymeric substances (EPS) by Serratia sp.1 using wastewater sludge as raw material and flocculation activity of the EPS produced. J Environ Manage 128: 83-91.

28. Mikkelsen LH, Keiding K (2002) Physico-chemical characteristics of full scale sewage sludges with implications to dewatering. Water Res 36: 2451-2462.

29. Houghton JI, Quarmby J, Stephenson T (2001) Municipal wastewater sludge dewaterability and the presence of microbial extracellular polymer. Water Sci Technol 44: 373-379.

30. Jin B, Marie WB, Lant $P$ (2004) Impacts of morphological, physical and chemical properties of sludge flocs on dewaterability of activated sludge. Chemical Eng J 98: 115-126.

31. More TT, Yan S, Hoang NV, Tyagi RD, Surampalli RY (2012)a Biochemical diversity of the bacterial strains and their biopolymer producing capabilities in wastewater sludge. Bioresour Technol 121: 304-311.

32. Buthelezi S, Olaniran A, Pillay B (2010) Production and characterization of bioflocculants from bacteria isolated from wastewater treatment plant in South Africa. Biotechnol. Bioprocess Eng 15: 874-881. 